\title{
Article:
}

\section{The involvement of family in child protection cases in Iceland}

by

\author{
Anni Haugen \\ Assistant Professor \\ University of Iceland \\ annihaug@hi.is
}

Sigrún Yrja Klörudóttir

Social Worker

Iceland

syk1@hi.is

\section{Keywords:}

family involvement, family construction, definition of family, attitudes towards fathers 


\section{Abstract}

The aim of this study is to examine the involvement of families in child protection cases in Iceland, as well as to shed light on the attitudes of child protection workers on the importance of including families while working on child protection cases. The study is part of an international comparative analysis called: Social Work with Families: Social Workers' Constructions of Family in Professional Practice. This article only addresses the Icelandic segment of the research. In the study, qualitative methods were used and three focus groups were conducted, in which the same three-step vignette about a child protection case was presented. The findings highlighted how difficult child protection workers found it to define the family. The main element is that family are those individuals closest to the child and connected to them through emotional ties, as Icelandic child protection workers seem to strive to involve family in child protection cases. However, there are signs which show that when working with more complicated cases the definition of a family becomes narrower, and involvement is restricted mostly to parents and grandparents. The findings also show that attitudes toward fathers differ from those toward mothers. The mother is expected to support and create security for the child, while the father is judged mostly on his violent behaviour and is not automatically regarded as providing support or actively taking responsibility for his child.

\section{Introduction}

Organized child protection in Iceland began in the first half of the last century, and from the beginning it had many similarities to child protection in the other Nordic countries. Cooperation between the Nordic countries in the field of child protection has a long and important history, influencing the policies created in all of the five countries (Andresen et al., 2011). The pioneering force behind the various services on offer for children originated with NGOs, and until the middle of the last century NGOs were involved in running a considerable part of social and health services. With the creation of the social services, the state and local governments took over the major part of these amenities (Hrafnsdottir, 2008).

In recent decades, child protection services have looked toward the family when a child needs support, and over the last few years the emphasis has increased on a more childcentred approach and on supporting the child in its own home and strengthening the parents in their parental role. In accordance with the UN Convention on the Rights of the 
Child, Icelandic legislation has a clear focus on the child as an individual, while at the same time acknowledging that the child is part of a family: the best place for the child to be raised when at all possible (Child Protection Act, No. 80/2002). Thus, the development in child protection work in Iceland is similar to the development in other Nordic countries (Gilbert, Parton, \& Skivenes, 2011).

This development is also in accordance with the Children's Act nr. $76 / 2003$, as well as numerous studies which have shown that it is more likely to have a positive effect for children when families are included (Gallagher et al., 2011). Studies have also shown that a change in parenting skills is one of the key factors for change in child behaviour (Gardner, Burton, \& Klimes, 2006). Therefore, while the focus has to be on the child, their safety and best interest, by involving parents it is more likely that they can fulfil their parental obligation to the child (Saint-Jacques, Drapeau, Lessard, \& Beaudoin, 2006).

However, who belongs to the family and who should be involved in child protection cases is not always clear, particularly in light of how families can vary. The Icelandic Child Protection Act clearly defines the rights and obligations of parents who have custody, but other individuals are also seen as being of importance to the child (Child Protection Act, No. 80/2002).

Despite this, parents are not involved to the same extent. The mother seems to be automatically involved and then her tasks vary, e.g. to ensure and monitor the child's safety, in addition to being responsible for the necessary changes. She is frequently given the role to act as a messenger between the child protection worker and the father (Haugen, 2012). Several studies have revealed the absence of fathers in child protection cases, that they do not participate in the cases in the same way or to the same extent as a mother does, and that little information about them exists in case files. This seems to be the case whether a father has or does not have custody rights (Kristinsdottir, 1991; Maxwell, Scourfield, Featherstone, Holland, \& Tolman, 2012). Interestingly, the child protection workers often appear to regard fathers as deviant, dangerous, irresponsible and absent regardless of whether he is a risk to the child and family or not (Brown, Callahan, Strega, Walmsley, \& Dominelli, 2009). Although fathers have long been absent in child protection cases, the focus on the father has increased over recent years, both in practice and research, and adolescent fathers in child protection cases are still 
under-identified and mostly invisible to child protection workers (Gordon, Watkins, Walling, Wilhelm, \& Rayford, 2011).

One reason for parents not being involved equally in child protection cases might be due to the fact that social work, especially with families, is not gender-neutral and most social workers (and child protection workers) are women. This could influence the way mothers and fathers are seen in child protection work, i.e. women are seen as oppressed and easy to identify, while men are abusive and useless (Oltedal, 2013; Scourfield, 2006).

In spite of the knowledge regarding the importance of involving the family in child protection, it is still unclear how child protection workers define the term family and what members of the family are actually involved in the work. One reason often given for not involving the family is the workers' caseload, and that building relationships with families takes time, which is something they do not feel they have (Gallagher et al., 2011).

In this article, we will discuss the Icelandic segment of the study, Social Work with Families (SWF): Social Worker's Constructions of Family in Professional Practice (Nygren \& Oltedal, 2014). The aim of this study is to gather knowledge about the involvement of family in child protection cases in Iceland. The purpose is to further examine the attitudes child protection workers have toward families when looking for possible support for the child, and if they do involve the family in what family members they choose. The research questions in this study are:

- How do child protection workers define the term family?

- How much emphasis do child protection workers place on family involvement in child protection cases?

- Which family members are likely to be involved in child protection cases?

First, we will describe some features of Icelandic society in order to put the findings in perspective. Subsequent to this, we will discuss the background and the methods of the research project before going on to the outcomes and a discussion of the findings.

\section{Families in Iceland}

Over the years, there have been various definitions of the term family within social science, and academics do not agree on a single definition of family, as views on family can change between societies and historically within societies (Hantrais, 2004; 
Juliusdottir, 1995a, 2001). The definition most often used in Iceland describes the family as:

.... group of individuals that live in the same residence and share hobbies, rest, emotions, finances, responsibilities and chores. Members are often adults of the opposite sex or individuals with their child or children. They are committed to each other in moral and mutual loyalty. (Juliusdottir, 1995b, p. 7)

This definition includes all family types; stepfamilies, lone-parent families and families with same-sex parents, but is restricted to families that share a household (Juliusdottir, 1995b, 2001).

Thirty-six percent of marriages in Iceland end in divorce (Statistics Iceland, nd.b), and more couples choose to cohabitate than to marry. A large majority of those that divorce or separate after cohabitating remarry or form a cohabitation again. Therefore, stepfamilies and lone-parent families are common, while $90 \%$ of parents who get divorced or separated share the custody of their children (Fridriksdottir, 2013).

In order to enable both parents to take care of their child, parental leave for both parents is ensured by law, and in 2010 the division of parental leave between parents was more equal in Iceland in comparison with the other Nordic countries (Duvander \& LammiTaskula, 2011; Eydal \& Gislason, 2008).

Iceland is a homogeneous society, in which only $6.7 \%$ of the residents were of foreign citizenship in 2013 (Statistics Iceland, nd.a). Same-sex couples have the same rights as heterosexuals in regard to marriage and the number of same-sex couples has grown substantially in recent years (Thingskjal [Parliamentary Document] 1302, 2010).

\section{Child Protection in Iceland}

The current Child Protection Act was enacted in 2002, and has been amended several times since then (Child Protection Act, no. 80/2002). An importance is placed on strengthening parents in their roles within the family and on the protection of children, as stated clearly in the article on the objectives of the Child Protection Act:

The objective of this Act is to ensure that children who are living in unacceptable circumstances or children who place their health and maturity at risk receive the necessary help. Efforts shall be made to achieve the objectives of the Act by strengthening families in their child raising role and applying measures to 
protect individual children when applicable. (Child Protection Act, no. 80/2002, 2nd art.)

Amendments to the Act have focused on strengthening the legal rights of the child and parents, as well as increasing efforts towards making the child more visible (Thingskjal [Parliamentary Document] 403, 2001-2002).

Despite this emphasis on seeing the family as a whole, many Icelandic studies have come to the same conclusion as other international studies, that it is the mother who is most often contacted in child protection cases (Maxwell et al., 2012; Haugen, 2012). Kristinsdottir (1991) discussed what she called the child welfare trap, in which the mother in particular is sought out and demands are made on her to care for and ensure the safety of the child, while the father is left alone with very little mention of him in the case files. Even though there are some signs indicating that the fathers do get more attention than before, the main focus is still on the mothers when support from family is sought in child protection cases (Gunnarsdottir \& Haugen, 2012). The Icelandic Child Protection Act defines the obligation individuals have to notify the child protection authorities, which includes the public, professionals who work with children and the police. These individuals are obligated to report to the child protection authorities if they have a reason to believe or become aware that a child is being neglected or abused or has put themselves at risk (Child Protection Act, no. 80/2002).

The resources and programmes available in child protection include support for the child such as advice, counselling, etc. and placement in foster homes or institutions. The aim of fostering is either for the child to live there temporarily and then return home to their parents or for a child to be fostered until adulthood, hence becoming part of another/new family (Child Protection Act, no. 80/2002). It has been more common for children to be fostered with strangers, although a small portion are fostered with relatives (Gudbrandsson, 2007). A fostered child has the right to have access to their parents and those individuals who are most important to them (Child Protection Act, No. 80/2002).

\section{Methods and analysis}

This qualitative study was based on grounded theory. When using grounded theory, data is systematically analysed in order to build a theory (Esterberg, 2002; Yegidis \& 
Weinbach, 2002). In this research, data was collected through focus group interviews using the same vignette as was used in the other countries that took part in the SWF project. By using focus groups, the researcher seeks to examine the social worker's opinions or attitudes toward families, and thus gather more information in a shorter amount of time than when conducting individual interviews (Esterberg, 2002). The focus group interviews were digitally recorded and then transcribed and analysed with open coding, which was followed by focused coding (Esterberg, 2002). Two codes were found when looking at how child protection workers define the family: living situations and quality of attachment. With regard to family involvement in child protection cases, three codes were found family first, attachment and support and mothers vs. fathers.

Three focus group interviews took place in September 2013. Two focus groups were held in the greater capital area and one in a rural area. Each focus group consisted of three to four participants, with 11 participants in total. All participants were child protection workers and with the exception of one, all were social workers and all were women. The participants in the focus groups were found with the help of the head of the child protection service in each area. In general, the participants had varying experience in child protection, ranging from a few months up to 25 years, and some of them also had experience working in social services.

The vignette used in the focus group interviews detailed a client's situation over a fouryear-period. The purpose of using a vignette was to analyse and clarify the judgement of the participants in relation to the involvement of families in child protection cases, and allow them to examine the situations provided in a way that was less threatening by using a hypothetical situation, rather than focusing on their own practice. The use of the same vignette in all of the countries participating in the project also enables participants to compare definitions and practice.

The vignette tells about the various circumstances in the life of Maria, who is an only child and lives with her parents. Her father is said to be violent, and both Maria and her mother are afraid of him when he becomes angry. Maria is close to her grandparents, who live in the same neighbourhood, but otherwise the family is quite isolated with little contact with other relatives who live in another district. 
In the first part of the vignette, Maria is 14 years old. She is six months pregnant and has not told anyone about her situation. She seeks the help of the school counsellor to tell her mother about the pregnancy, and she thinks it is best if her mother takes care of her child until Maria turns 18 years old. The father of Maria's child is Peter, who is two years older than her. They had a short relationship, though it is now over. In the next part of the vignette, Maria is 16 years old and has a two year-old daughter named Penny. Maria is struggling with raising her daughter, and has agreed to allow Penny to be fostered. Additionally, the violence between Maria's parents has increased over the last two years. Therefore, Maria cannot live there and has to live in supported housing within the community. In the third part of the vignette, Maria is 18 years old and wants her daughter to live with her. According to Maria, she has a job and is emotionally stable. Over the last two years, Penny has moved between foster families and has been violent towards other children when they are playing. Maria and Penny have met roughly one weekend a month over the last two years, and Maria feels she can offer her daughter more stability than she gets at the moment. In any case, no account is made for where Maria has lived over the past two years or where she lives now.

\section{Results}

The results of the study are presented according to the research questions and the codes that were found. As previously mentioned, there were three research questions: how child protection workers define the term family, how much emphasis do they place on family involvement in child protection cases and which family members were most likely to be involved.

When analysing the findings, two codes were found for the first research question: Living situations and Quality of attachment. The other research questions were viewed together as "Family involvement in child protection work", and three codes were found: Family first, Attachment and support and Mothers vs. fathers.

\section{Child protection workers' definition of family}

The participants found it difficult to describe the term family, and considered it even more problematic today than a few decades ago. Consequently, their definitions became vague, "If I had gotten that question 20 to 30 years ago, the answer would have been something like mother, father, children and a car." They referred to some of the changes 
that have occurred within society over the last decades, such as the increase in stepfamilies, lone-parent's families and families with same-sex couples.

\section{Living situation}

When describing the family, the participants used terms such as: "those who share a home in some way", and did not talk about a specific family form, stressing that households could vary. They distinguished between the extended family and the nuclear family, clearly focusing more on the latter. By defining families in this manner, they did not only take into consideration those who live in the same household, but also that a child can have more than one home and therefore be a part of two nuclear families:

I would probably begin to define it as those who... see... live with the child... see... some live at home and are always there. But those who sleep there sometimes have a sort of home there as well.

...yes, a family is just people that live together and are emotionally attached.

\section{Quality of attachment}

All of the participants agreed that biology was no longer a necessary basis to be included in the definition of family, and that first and foremost it is the quality of the relationship that makes a group of people a family:

...I think family is more those who are closest to the child... support them in some way. Where there is support, love, someone you can trust and it is not necessary, definitely not necessary, to be someone related by blood.

According to the participants, the definition of family differs depending on your own focus. When working within the child protection services, family is to a large extent defined by the child itself, i.e. as those who are close to the child, care for them and are emotionally connected to the child. In general, it was stated that in social service practices an individual can be regarded as a family if she/he has no other relatives.

The participants also discussed step relatives and stepfamilies. The family of the stepparent, such as the parents of the stepparent, were considered family if their relationship to the child was good. Previous stepparents were also counted as family, even when the relationship with the child's parent was dissolved. Thus, the participants 
felt that if the child had a good relationship with a former stepparent, who also provided the child with support, then they were considered a part of that child's family:

It's not just blood relations, but step relations as well, and parents could have had many spouses and some of the previous spouses could still have a connection with the child, offering support and being somehow important to the child and therefore considered a part of the child's family.

\section{The involvement of families in child protection work}

Throughout the discussion, the focus was on Maria being a part of a family and her relationship with family members. One of the first comments in all of the groups was that the school counsellor, who Maria asked for help, had to notify the child protection authorities about the case, not because Maria was pregnant, but because she was living in an abusive environment. The school counsellor was regarded as someone who Maria trusted, and was therefore seen as important support for her. For this reason, the first part of the discussion was concentrated around questions such as what would be the role of the school counsellor, was it her role to inform Maria's mother, should she contact Peter and his family etc., or would her primary role be to notify child protection authorities and maybe follow Maria to meetings with child protection or take her to prenatal care.

There was an overall agreement that Maria's case belonged within the child protection system, and that NGOs would not have any specific role in the work. The child protection service's role was to make sure she was safe from violence, assess her needs, listen to what she wanted, empower her and support her. Throughout the discussion, questions were asked about what Maria's main problem was: if it was her young age in being a mother, her abusive father or something else. In all three phases of the vignette, there was a clear focus on the need for assessment and family meetings.

\section{Family first}

The focus group's discussion of Maria's difficult situation showed that it was never questioned whether support should be sought from her immediate environment, but rather the question was who could offer her the support she needed. In fact, the participants in the focus groups were surprised that Maria's extended family was not involved in a more active way. The participants stressed the importance of involving family members and seeking support from the child's environment whenever possible: 
Yes I think we greatly respect the family and it is just a part of our professional work to keep it together as long as possible, as long if the children are not harmed.

It was obvious that the participants looked at the family as crucial for the child, and that the child should remain within the family if possible: "It is certainly worth it for the child to remain within the family."

Some of the participants argued that the focus in child protection work is still on the mother, and the reason for this may have been old habits, a lack of time and a too heavy caseload. Others protested and claimed that the focus today is also on the father, and that an effort has been made to involve him in child protection cases.

\section{Attachment and support}

The main thread throughout the interviews was that Maria's relationship with possible beneficial individuals was the starting point for approaching a possible support person. As it was stated in the vignette, Maria and her parents had little contact with other family members, and the participants vaguely discussed whether there would be anyone outside the family who she was in close contact with that could help support her.

There was a strong reaction in all of the focus groups to Maria's circumstances at the age of 16. At this point in the vignette, Maria had agreed for her daughter to be placed in a foster home, as she had trouble raising her and Maria could not live at home due to her father's increasingly violent behaviour. The vignette did not describe the type of trouble Maria had in raising her daughter, and the participants wondered if these problems were related to the circumstances in which they lived. The participants discussed the possibility of Maria being able to better raise her daughter in a different environment, although they also strongly doubted that a solution could not be found where Maria could stay with her daughter and receive the support she needed to raise her:

OK, she has had trouble raising her daughter, but do you know what these problems are? Is it her lack of ability or is it because of the circumstances? Would it be possible for her to raise her if the circumstances were better? 
Maria's grandparents, who lived in the same neighbourhood, were considered as a possible support for her. Staying with them was thought to be a safe place if the assessment showed that both the relationship between the grandparents and Maria was good, and that they could offer her the support she needed.

\section{Mother vs. fathers}

The discussion indicated that it is not automatically assumed that parents can give children the support they need. Maria's father, who had been violent towards Maria and her mother, was only regarded as hostile and therefore a danger to his daughter and granddaughter. None of the participants mentioned him as a possible support for Maria, and no one raised a question about the relationship between the two of them, or if he could be any sort of resource for her. The discussion of Maria's father mostly focused on how to tell him about Maria's circumstances, where it should be done and who should tell him. There were also disagreements as to whether Maria's parents should be told about her pregnancy at the same time or whether her mother should be told first. There was a general agreement that Maria needed help in telling her father about the pregnancy, since his reaction was expected to be abusive. Her father seemed to be seen as part of the problems Maria had to face through all three parts of the vignette: "It may also be a question of who deals with the father."

There were clear expectations from the participants for Maria's mother to stand by her daughter's side and be a support for her. Part of the reason for this could be that Maria had wanted her mother to raise the child she was carrying. Due to the violence Maria's mother lived with, the participants questioned her ability to offer Maria the support she needed, and they felt that Maria's mother should leave her husband due to the violence: "Her mother has obviously not been able to break up with the father so she might not be the support for Maria we had hoped for." The participants agreed that Maria could only live in her home if her mother left her husband.

In the discussions, the focus on Penny's father Peter was vague, as there was some speculation about in what way he would be a part of his daughter's life, but no clear opinions on his role as a father. It was regarded as important to inform him and his parents that he was expecting a child with Maria. When it became clear that Penny had to be fostered, the possibility was discussed as to whether she could be fostered with 
Peter's parents instead of with strangers. The participants wondered if Peter had had any contact with his daughter while she was in a foster home. They also talked about the possibility of the girl staying with her father every other weekend or so, or if Maria would get her back when she turned 18 .

When Peter's role in his daughter's life was discussed, it was usually in the same breath as his family, and he was not mentioned as a father and a caregiver on his own. Nonetheless, whether it was due to his young age or that he was male and not female is not evident.

\section{Discussion}

The participants openly discussed how complicated it is to define the term family. It was stated that it is more difficult to define the family nowadays than has previously been the case, as families in Iceland are more diverse in form than ever before due to recent social changes.

It is interesting to notice how vague the definition of family has become and in some ways contradictory. When defining family in general the ideas of the participants were quite similar, with most of them thinking about the family from the view of a child and the considered individuals in the child's close environment as being attached by emotional bonds as a family. They did not feel that biology was a necessary premise for family, but rather that the relationship and the quality of it is what made a group of people a family. For instance, this could include members of a former stepfamily if the relationship is good or a family member who does not live in the home all the time, as some children have two homes and are part of two families, i.e. both the mother's and the father's family. The participants also considered those individuals who share a home in some way to be a family, whether they were blood relations, step relations or some other type of relation. This is very close to the common definition often used in Iceland and discussed earlier in this paper, which is quite wide and encompasses most family forms known today. This definition is also similar to those in social work and other fields of research, who define a family as those who live in the same household and are emotionally connected (Juliusdottir, 1995b, 2001). Some of the participants mentioned that the definition of family varied depending on the angle from which it was accessed. They argued that when working within the social services that an individual might be 
regarded as family. It would be interesting to do some further study in this area in order to see if and what kind of consequences this definition has for the service he/she receives. It also raises the question of whether the participants consider a child to be a necessary prerequisite for being a family.

The results of the study indicate that the Icelandic child protection service considers it important for professionals to include family members in child protection cases. In spite of this, the definition of family became somewhat narrower when the participants discussed the vignette and was mostly restricted to parents and grandparents, with hardly any suggestions of involving other individuals who might be related to the child. In their daily practice, the blood relation and the closest family seem to support their theory of the family as those who are close to the child. The consequences of that could be that the child loses the opportunity to receive support from people outside the immediate family when problems arise and child protection becomes involved.

The participants found it difficult to understand the decision taken to place Maria and Penny in different programmes, and wanted to focus more on Penny than the vignette did. It was assumed that it would have been best to place both of them in a foster- or support home, where Maria would receive the help she needed to raise her daughter. Hence, the group strongly agreed on the importance of making it possible for the mother, Maria, and her daughter Penny to stay together and to have a close relationship. The two of them were defined as a family and that it was the role of child protection to keep the family together whenever possible, and here there was a strong emphasis on the blood relation between mother and child.

Key family members who were to be involved in child protection cases are the parents, especially the mother. The reason for this might be that parents are generally seen as the main support system in an individual's life based on the strong bonds between a parent and child, which usually last a lifetime. Another reason for this may be that parents must automatically participate in child protection cases in accordance with the Children's Act nr. 76/2003. Furthermore, there is a strong view on the importance of children growing up in their own family, both in Icelandic society and according to the UN Convention on the Rights of the Child (Act nr. 19/2013). Great attention and expectation was given to Maria's mother, who was considered to be her most viable support. This is 
not surprising, as numerous studies have shown that it is usually the mother who gets the primary attention in child protection cases, and is expected to protect, care for- and support her child (Haugen, 2012; Kristinsdóttir, 1991). Nevertheless, her ability to help Maria was brought into question due to the violence she endured from her husband.

The participants regarded Maria's father's behaviour as a serious issue. He was only seen as a violent man that the child protection workers had very limited contact with. It was never mentioned whether the father's situation should be investigated further, how his relationship with his daughter had developed, if he could support his daughter in any way or what measures were available for him to deal with his violent behaviour in order to make it possible for Maria and her daughter to stay in the home. These views are consistent with other studies on fathers in child protection, and need to be further challenged (Scourfield, 2003).

In the focus groups, the other man in the vignette, the father of Maria's child, Peter, also received a limited amount of attention. Although he does not have custody of his daughter, and is therefore not automatically mandated to be involved in the child protection case, it was regarded as important to explore whether he was capable of offering their child the support she needed with the help of his parents. Thus, he was mostly mentioned alongside with his parents, both in discussions of informing him about Maria's pregnancy and when it became necessary to place his daughter in a foster home. The participants also wondered whether his parents could care for the child, while no demand was made on Peter to take responsibility for raising his daughter on his own. Other studies have also shown that teenage fathers have been almost invisible in research and studies regarding the roles of the father, not only within child protection but generally speaking (Gordon et al., 2011).

The attitudes that participants showed toward these two men are interesting when seen in light of their definition of family and the statements about fathers now becoming more involved in child protection work. In the overall discussion on families, it was mentioned that child protection worker's lack of time and routine led to the focus on the mother, a view that needs to be confronted. These findings also highlight the importance of further research on the real involvement of fathers in child protection cases. It would also be interesting to see if an increase in paternity leave would lead to fathers taking a more 
active part in the care of their children, and if that would be reflected in the families that child protection meets.

In the findings, grandparents were mentioned as a possible support for Maria. The question of how her relationship with them has been the key to involving them in her situation as some kind of support.

There have been many changes in the role of family and in child protection programmes over recent decades. Today, the involvement of families in child protection work is said to be given a greater role at the same time that the focus is on the child. This study raises question about whether this is really so, particularly when noticing the role that the mother and the father(s) are given. The mother is expected to help and support her daughter and to give up a supposedly abusive husband. The father is excluded and only seen as a threat, and there are no expectations of the father to the child. If this is a general attitude towards families within child protection work, then the child could miss out on important relationships, as well as valuable support. One can also ask if a more child-focused work could lead to a type of "blindness" towards the support within families, since child protection workers might see it as a contradiction to keep a child-centred focus, in addition to family members such as mothers, fathers and other individuals the child could have a safe, stable relationship with. Due to the size of the study, it is difficult to draw any general conclusions, but it does indicate the importance of further research in Iceland, as well as comparative research with other countries in order to acquire a better understanding of how social workers in child protection define the rapidly changing definition of family, who they look toward to offer the child support and what this means for child protection work. 


\section{References}

Andresen, A., Gardarsdottir, O., Janfelt, M., Lindgren C., Markkola P., \& Söderlind, I. (2011). Barnen och välfärdspolitiken: Nordiska Barndomar 1900-2000. Stockholm: Dialogos.

Barnalög [Children's Act] nr. 76/2003.

Barnaverndarlög [Child Protection Act] nr. 80/2002.

Brown, L., Callahan, M., Strega, S., Walmsley, C., \& Dominelli, L. (2009).

Manufacturing ghost fathers: The paradox of father presence and absence in child welfare. Child and Family Social Work, 14, 25-34.

Duvander, A. \& Lammi-Taskula, J. (2011). Parental leave. In I. V. Gislason, \& G. B. Eydal (Eds.), Parental leave, childcare and gender equality in the Nordic countries (pp. 31-64). Copenhagen: Nordic Authority of Ministers.

Esterberg, K. G. (2002). Qualitative methods in social research. Boston: McGraw-Hill.

Eydal, G. B., \& Gislason, I. V. (2008). Paid parental leave in Iceland, history and context. In G. B. Eydal, \& I. V. Gislason (Eds.), Equal rights to earn and care: Parental leave in Iceland (15-44). Reykjavik: Social Research Institute, University of Iceland.

Fridriksdottir, H. (2013). Handbók. Barnalög nr. 76/2003 með síðari breytingum. Reykjavík: Ulfljotur and the Ministry of the Interior.

Gallagher, M., Smith, M., Wosu, H., Stewart, J., Hunter, S., Cree, V. E. et al. (2011). Engaging with families in child protection: Lessons from practitioner research in Scotland. Child Welfare, 90(4), 117-134.

Gardner, F., Burton, J., \& Klimes, I. (2006). Randomised controlled trial of a parenting intervention in the voluntary sector for reducing child conduct problems: Outcomes and mechanisms of change. Journal of Child Psychology and Psychiatry, 47(11), 1123-1132.

Gilberg, N., Parton, N., \& Skivenes, M. (2011). Changing patterns of response and emerging orientations. In N. Gilbert, N. Parton, \& M. Skivenes (Eds.), Child protection systems International trends and orientations (243-259). New York: Oxford University Press.

Gordon, D. M., Watkins, N. D., Walling, S. M., Wilhelm, S., \& Rayford, B. S. (2011). Adolescent fathers involved with child protection: Social workers speak. Child Welfare, 90(5), 95-114.

Gudbrandsson, B. (2007). Barnavernd og uppeldisstofnanir: Saga stofnana fyrir börn og samfélagsbreytingar um miðja 20. öld. Greinargerð unnin í tilefni af könnun nefndar samkvæmt lögum nr. 26/2007. Retrieved March 26. 2015, from http://www.forsaetisraduneyti.is/media/Skyrslur/Breidavik_skyrsla_2.pdf. 
Gunnarsdottir, M., \& Haugen, A. G. (2012). Stuð̃ningsúrræðið tilsjón í barnaverndarmálum. Tímarit félagsráogjafa, 1(6), 13-20.

Hantrais, L. (2004). Family policy matters: Responding to family change in Europe. Bristol: The Policy Press.

Haugen, A. G. (2012). "Pað kemur alveg nýtt look á fólk" Rannsókn á gerđ áætlana um meðferð máls í barnaverndarmáli. Reykjavik: RBF.

Hrafnsdottir, S. (2008). Frjáls félagasamtök og sjálfboðaliðastörf á Íslandi. In O. H. Kristmundsson, \& S. Hrafnsdottir (Eds.), Stjórnun og rekstur félagasamtaka (pp. 21-42). Reykjavik: University of Iceland Press.

Juliusdottir, S. (1995a). Fjölskyldukenningar og rannsóknir. In S. Juliusdottir (Ed.), Barnafjölskyldur: Samfélag, lífsgildi, mótun (11-38). Reykjavík: Gutenberg.

Juliusdottir, S. (1995b). Formáli. In S. Juliusdottir (Ed.), Barnafjölskyldur: Samfélag, lífsgildi, mótun (7-10). Reykjavik: Gutenberg.

Juliusdottir, S. (2001). Fjölskyldur við aldahvörf: Náin tengsl og uppeldisskilyrði barna. Reykjavik: Háskólaútgáfan.

Kristinsdottir, G. (1991). Child welfare and professionalization. Umeå: University of Umeå.

Lög um samning Sameinuðu pjóðanna um réttindi barnsins [Act regarding the UN CRC] nr. 19/2013.

Maxwell, N., Scourfield, J., Featherstone, B., Holland, S., \& Tolman, R. (2012). Engaging fathers in child welfare services: A narrative review of recent research evidence. Child \& Family Social Work, 17, 160-169.

Nygren, L., \& Oltedal, S. (2014). Social workers' understanding of 'family' in child welfare work - an international research approach. In S. Hessle (Ed.), Global Social Transformation and Social Action: The Role of Social Workers (123127). Surrey: Ashgate Publishing Limited.

Oltedal, S. (2013). Kjønnsperspektiv i sosialt arbeid. Oslo: Universitetsforlaget.

Saint-Jacques, M.C., Drapeau, S., Lessard, G., \& Beaudoin, A. (2006). Parent involvement practices in child protection: A matter of know-how and attitude. Child and Adolescent Social Work Journal, 23(2), 196-215.

Scourfield, J. (2003). Gender and Child Protection. London: Palgrave.

Scourfield, J. (2006). Gendered organisational culture in child protection social work. Social Work, 51(1), 80-83. 
Statistics Iceland. (nd.a). Ríkisfang, fæðingarland og bakgrunnur íbúa. Erlendir ríkisborgarar. Retrieved December 12, 2014, from http://hagstofa.is/Hagtolur/Mannfjoldi.

Statistics Iceland. (nd.b) Mannfjöldi. Retrieved December 12, 2014, from www.hagstofa.is/pages/974.

Thingskjal [Parliamentary Document] 403. (2001-2002). Frumvarp til barnaverndarlaga. Retrieved December 12, 2014, from http://www.althingi.is/altext/127/s/0403.html.

Thingskjal [Parliamentary Document] 1302. (2010). Lög um breytingar á hjúskaparlögum og fleiri lögum og um brottfall laga um staðfesta samvist (ein hjúskaparlög). Retrieved December 12, 2014, from www.althingi.is/altext/stit/2010.065.html.

Yegidis, B. L., \& Weinbach, R. W. (2002). Research methods for social workers. Boston: Allyn and Bacon. 